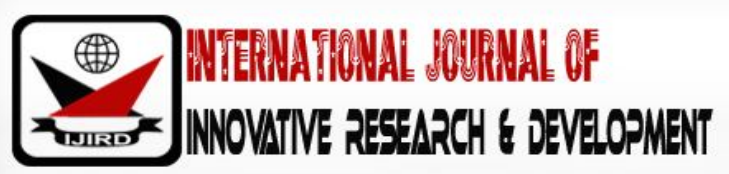

ISSN 2278 - 0211 (Online)

\section{The Effect of the Fundamental Factors against Bank Stock Price Listed in Indonesia Stock Exchange Period 2013-2015}

Said Djamaluddin
Postgraduate Lecturer, Mercu Buana University, Jakarta, Indonesia
Rika Mirza Arisandy
Postgraduate Alumni, Mercu Buana University, Jakarta, Indonesia
Djumarno
Postgraduate Lecturer, Mercu Buana University, Jakarta, Indonesia

\begin{abstract}
:
This study aims to test empirically the influence of Non Performing Loans, Return on Assets, Earning per Share, Capital Adequacy Ratio, Operational Revenue Operating Expense, and Loan to Deposits Ratio to the shares price of banks listed on the Indonesia Stock Exchange, partially and simultaneously. This research uses descriptive study through hypothesis testing by using causal design. The sample in this research are 28 banking companies listed in Indonesia Stock Exchange period 2013-2015. Data analysis techniques using the application program Econometric Views (Eviews 8.0). The result of the research shows that (1) Non Performing Loans partially have negative and significant influence on shares price, (2) Return on Assets partially have negative and significant influence on shares price, (3) Earning per Share partially have positive and not significant influence on shares prices and (4) Capital Adequacy Ratio partially has a positive and significant influence on shares prices, (5) Operational Revenue Operating Expenses partially have a negative and significant influence on shares prices, (6) Loan to Deposits Ratio partially have a negative and not significant influence on shares prices (7) Non Performing Loans, Return on Assets, Earning per Share, Capital Adequacy Ratio, Operating Revenue Operating Expense, and Loan to Deposits Ratio jointly have a significant influence on shares prices.
\end{abstract}

Keywords: Share price, fundamental factors

\section{Introduction}

The capital market is a market for various long-term financial instruments that can be traded, whether bonds, equity (stock), mutual funds, derivative instruments or other instruments. Capital market financial function is to provide funds needed by other parties without having to be dir ectly involved in the company's operations (Husnan, 2005). Stock is one of the most investment instruments offered by the company and most in demand by investors because the stock is able to provide higher profit levels than other investment instruments and with a higher level of risk.

According to Amanda and Wahyu (2013), banking stocks are the most popular stocks and have reportedly outperformed the growth of the Jakarta Composite Index (IHSG), although in mid-1997 and in the 2008 global financial crisis the banking sector fell and experienced a decline in performance. Over time, the banking sector is able to prove its existence in performance and achievement of good results so that investors are interested in buying shares again.

Stock price is one indicator of the success of corporate management, if the stock price of a company always increases, then investors or potential investors judge that the company managed in managing its business. This will make investors more selective and more cautious in taking stock investment decisions in the banking sector.The development of the capital market is one indicator that continues to be monitored starting from the transaction value and transaction volume, market capitalization, the number of issuers, and the Composite Stock Price Index (IHSG). The movement in the capital market is strongly influenced by the expectations of its players formed by a combination of fundamental, technical, and sentiment factors. If there is a positive expectation, interest in buying will increase which will move the price up. Conversely, negative expectations will drive prices down as selling pressure increases. 


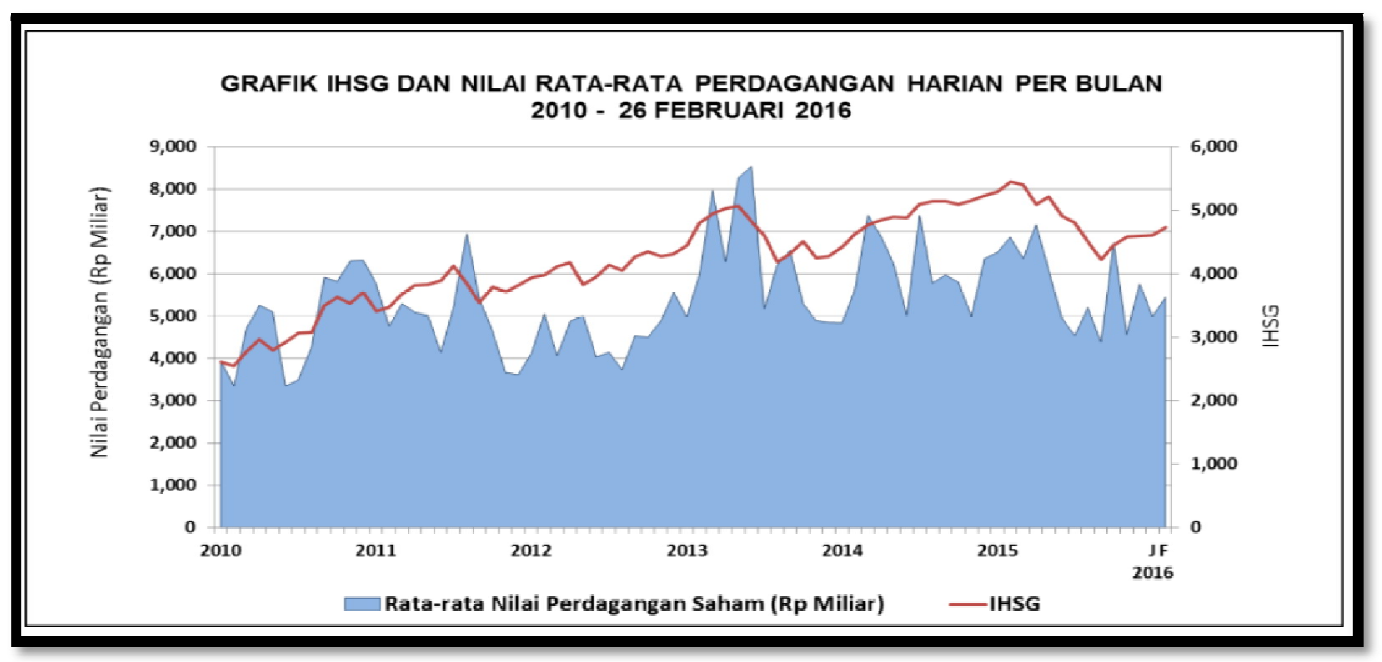

Figure 1: JCI Chart and Daily Stock Trading Average

From picture 1 The picture above shows the movement of banking stock price traded in Indonesia Stock Exchange (BEI). The importance of research on the impact of fundamental factors on stock prices of banking companies. Another consideration is that stocks traded on the IDX are generally very sensitive to macro-indicator fluctuations such as inflation, interest rates, foreign exchange rates and monetary policy, in addition to the bank's fundamental factors. It should be a fundamental aspect that is directly related to the performance of banks that have a strong enough influence on stock prices. In connection with this case through this study tried to find empirical evidence.

Previous research by Fariz Abdullah and L. Suryanto (2015) on the Influence of Bank Health Ratios on Stock Price states that Non Performing Loans (NPL), Return on Assets (ROA), Earning Per Share (EPS), Capital Adequacy Ratio (CAR ), Operating Revenue Operating Expense (BOPO) and Loan to Deposits Ratio (LDR) together significantly influenced the stock price. Based on the background of the above thought, the researcher is interested to conduct research entitled "The Influence of Fundamental Factor on Stock Price of Banks Listed on Indonesia Stock Exchange Period 2013-2015".

\section{Theoretical Review}

Stock Shares are identical to risk. This is in accordance with the characteristics of stocks "high risk- high return" which illustrates the higher profits expected by investors, the higher the risks that must be faced to realize the benefits. Stocks (stocks) are one of the best known financial market instruments and are able to attract the attention of investors because stocks promise higher profits than other instruments.

The stock price according to David and Kurniawan (2010: 01) is the price formed on the stock market and generally the stock price was obtained to calculate the value of the stock. Jogiyanto (2010:130) said the stock price is the price of a stock that occurs in the stock market at a certain time determined by market mechanism in the form of demand and supply of shares. It can be concluded that the stock price is the price of a piece of stock that occurs at a certain time determined by demand and supply in the capital market. The share price itself is the proof value of the shares where the shares are outstanding (outstanding securities). The price of a stock can also be defined as the price formed by the interaction between the sellers and the stock buyers who are motivated by their expectations of corporate profits.

\section{Fundamental Factors}

\subsection{Non Performing Loans (NPL)}

In conducting lending to customers, the bank will be exposed to credit risk that can not be paid by the debtor causing non-performing loans. According to Rivai (2013: 398), the definition of non-performing loans is a credit that has the possibility of risk in the future in the broad sense. NPL (Non Performing Loan) is the ratio between non-performing loans to total loans. This ratio indicates that the higher the NPL ratio indicates the worse the credit quality (Riyanto, 2011).

The smaller the NPL, the smaller the credit risk borne by the bank. The bank in credit shall conduct an analysis of the borrower's ability to repay its obligations. After credit is granted, banks are required to monitor the use of credit and the ability and compliance of the debtor in fulfilling its obligations. The Bank conducts a review and binding of the collateral to minimize credit risk. Banking practitioners agree that the safe limit of a bank's NPL should not exceed 5\%.

\subsection{Return on Assets (ROA)}

Return On Assets (ROA) is a ratio showing the ratio between net income and total bank assets, this ratio shows the level of asset management efficiency performed by the bank concerned (Frianto, 2012: 71). Fahmi (2011: 135) suggests, ROA ratio measures the effectiveness of management as a whole is directed by the size of the profits obtained 
in relation to sales and investment. The better the profitability ratios the better the ability to capture the high profits of the company. Return on Assets (ROA) is one form of profitability ratios used to measure the ability of the company with the overall funds invested in assets used for the company's operations in generating profits generated from the results for the net profit of the company against the book value of total assets of the company.

\subsection{Earning per Share (EPS)}

Earning Per Share is a form of profit given to shareholders of every share owned (Fahmi,

2012: 97). Financiers often focus on earnings per share (EPS) in the analysis. EPS figures are usually presented at the bottom of the income statement, and are therefore often referred to as the bottom line (Husnan, 2005: 328). Profit is a key measure of the success of a company, therefore investors often focus on the amount of Earning Per Share (EPS) in conducting stock analysis. The higher the value of EPS, of course, encouraging shareholders because of the greater profits provided to shareholders.

\subsection{Capital Adequacy Ratio (CAR)}

Dendawijaya (2015:121) describes CAR (Capital Adequacy Ratio) is a ratio that shows how much the total assets of banks that contain elements of risk (credit, inclusion, securities, bills with other banks) that come financed from the bank's own capital, Funds from sources outside the bank. While Kuncoro and Suhardjono (2011: 519) define CAR is the capital adequacy that shows the ability of banks in maintaining adequate capital and the ability of bank management in identifying, measuring, supervising, and controlling risks arising that may affect the amount of bank capital. Capital is a very important factor in the development of business and to accommodate the risk of loss. Capital owned by banks based on the obligation of minimum capital provision of banks. The percentage of minimum capital requirement required by the Bank of International Settlements (BIS) is called Capital Adequacy Ratio (CAR).

\subsection{Beban Operasional Pendapatan Operasional (BOPO)}

According to Veithzal Rivai (2013: 131), BOPO is the operational cost of operating income is the ratio used to measure the level of efficiency and ability of banks in conducting its operations. Furthermore, according to Hasibuan (2011: 101) suggests BOPO is Operational Cost to Operating Income (BOPO) is a comparison or ratio of operational costs in the last 12 months against operating income in the same period. BOPO ratio is the ratio of the ratio between operational costs and operating income. BOPO ratio is used to measure the efficiency and ability of banks in conducting their operations. The bigger the BOPO, the smaller or decreasing the banking financial performance. Vice versa, if BOPO is smaller, it can be concluded that the banking financial performance is increasing or improving (Ambo, 2013).

\subsection{Loan to Deposits Ratio (LDR)}

Loan to Deposit Ratio (LDR) according to Martono (2012: 82) states that "Loan to Deposit Ratio is a ratio to determine the ability of banks to repay liabilities to customers who have invested with loans that have been given to the debtornya." Dendawijaya (2015: 116) defines the Loan to Deposit Ratio is a measure of how far the ability of banks to refinance the withdrawal of funds by depositors by relying on the credit given as a source of liquidity. From the explanation shows that the Loan to Deposit Ratio (LDR) is the ability of the Bank to pay back the withdrawal funds that have been done by depositors by relying on credit to know the level of liquidation. Loan To Deposit Ratio (LDR) that is too high to give an indication of the lower ability of bank liquidity is concerned, this is because the amount of funds needed to finance the credit becomes greater. Conversely, if the low Loan to Deposit Ratio shows a low rate of credit expansion compared to the funds it receives.

\section{Research Methods}

This study uses descriptive study through hypothesis testing by using a causal design, that is to analyze the influence of one variable with other variables. The type of research used is explanatory research (explanatory research) because the main reason of explanatory research is to test the hypothesis proposed. This study aims to test empirically the influence of fundamental factors on stock prices of banks listed in Indonesia Stock Exchange Period 2013-2015.The stock price in this study is seen from the average Closing Price of the company's stock price 15 days on the date of publication of the financial statements. Based on the calculation, obtained data of bank stock price listed in Indonesia Stock Exchange year 2013-2015.

$$
\text { Stock Price }=\quad \text { Stock Price } t+1+\text { Stock Price } t+15
$$

According Yanuar (2012) stock price 15 days after the publication will be seen fluctuations. Where if the Annual Financial Report is not good will see a decrease in the stock price of the company. 
This share price represents a bank's reputation or the conclusions of bank soundness. When the soundness of the bank is judged to be good it will affect the price of its shares, which usually the stock price will increase because it is able to attract a lot of investor demand to invest the money in these shares. Fundamental factors studied in this research are as follows:

\subsection{Non Performing Loans (NPLs)}

NPL (Non Performing Loan) is the ratio between non-performing loans to total loans. The NPL ratio can be calculated by the following formula:

$$
\text { NPL }=\frac{\text { Problem loans }}{\text { Total credit }} \times 100 \%
$$

4.2. Return on Assets (ROA)

Return On Assets (ROA) is a ratio that shows the ratio between net income with total assets ROA bank measured by the formula:

$$
\text { ROA }=\frac{\text { Net profit }}{\text { Toial assets }} \times 100 \%
$$

4.3. Earning per Share (EPS)

Earning Per Share is a form of profits granted to shareholders of every share owned. Earninper share can be calculated by the formula:

$$
\text { EPS }=\frac{\text { Profit after tax }}{\text { Ordinary shares outstamding }} \times 100 \%
$$

4.4. Capital Adequacy Ratio (CAR)

Capital Adequacy Ratio is that serves to accommodate the risk of losses that may be faced by the bank. CAR is calculated by the formula:

$$
\mathrm{CAR}=\frac{\text { Canital weichted }}{\text { Total risk }- \text { weighted assets }} \times 100 \%
$$

4.5. Beban Operasional Pendapatan Operasional (Bopo)

$\mathrm{BOPO}$ is the operational cost of operating income is the ratio used to measure the level of efficiency and ability of banks in conducting their operations.

$$
\text { BOPO }=\frac{\text { Onerational Fxn enses }}{\text { Operating Income }}
$$

\subsection{Loan to Deposits Ratio (LDR)}

Loan to Deposit Ratio (LDR) is the ratio of the ratio between the amount of funds disbursed to the community (credit) with the amount of public funds and own capital used. The Loan to Deposit Ratio ratio can be calculated by the formula:

$$
\text { LDR } \quad=\frac{\text { TotalLoan }}{\text { Total Deposit }}
$$

The population in this study is a banking company listed on the Indonesia Stock Exchange 2013-2015 that until now registered amounted to 43 banks. The technique of determining the sample using purposive 
sampling is the determination of samples with certain considerations. Considerations taken include:

- Banks are listed on BEI prior to 2013

- The Bank publishes complete financial statements for the period 2013-2015.

- The Bank has not suffered any losses in the period 2013-2015

Based on these criteria, then obtained the number of samples in this study are 28 banking companies listed on the Indonesia Stock Exchange period 2013-2015.

The type of data used in this study is secondary data. Secondary data according to Sugiyono (2012:137) is "Source data that does not directly provide data to data collectors, for example through others or through documents". Secondary data, among others, presented in the form of data, documents, tables on the topic of research. The data used in this study is the annual report of each sample company from 2013-2015 taken from the media published by the Indonesia Stock Exchange, www.idx.co.id. And daily stock prices obtained from www.yahoofinance.com.

Methods of data collection in this study is by the method of documentation of secondary data in the form of financial statements of each company. This research data is obtained from the official website www.idx.co.id and other sources relevant to the data required. In addition, researchers also use the method of literature, namely data collection methods that are theoretical about the problems associated with this research. This method is done by reading literature books, references and other literature related to research.

Data analysis technique used in this study is statistical analysis method with multiple regression equation (multiple regression) by using application program Econometric Views (Eviews 8.0). Setiawan and Endah (2010) argue that panel data is a combination of periodical data (time series) and individual data (cross section). The panel data regression model can be formulated with (Nachrowi and Usman, 2012: 310):

$$
\text { Yit }=\alpha+\beta 1 \mathrm{X}_{1 i t}+\beta_{2} \mathrm{X}_{2 \mathrm{it}}+\beta_{3} \mathrm{X}_{3 i t}+\beta_{4} \mathrm{X}_{4 i t}+\beta_{5} \mathrm{X}_{5 i t}+\beta_{6} \mathrm{X}_{6 \mathrm{it}}+\varepsilon
$$

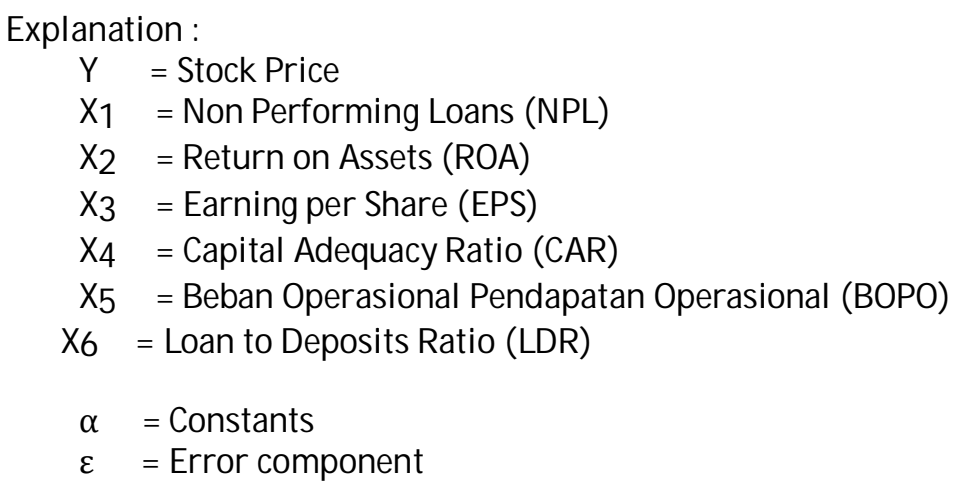

In the research using panel data, known 3 (three) research model approaches, namely Common Effects (pooled least square-PLS), Fixed Model Effect (FEM) and Random Model Effect (REM). The purpose of model estimation is to determine which model is suitable for this research. The analysis used in this research is multiple regression analysis model by using hypothesis testing. The modern interpretation of regression is the study of the dependence of one dependent variable with one or more independent variables, in order to estimate and / or predict the average dependent variable based on the value of the known independent variable. test).

To test the hypothesis to be analyzed ( $\mathrm{H} 1$ - H6), hypothesis tested by partial test ( $\mathrm{T}$ test) and simultaneous test (F

T Test (Partial)

This test is conducted with the aim to show how far the influence of one independent variable individually in explaining the variation of the dependent variable (Winarno, 2009: 34). At the 5 percent significance level, the basis for decision-making is as follows:

- If tarithmetic <ttable then $\mathrm{H}_{0}$ is accepted and $\mathrm{H}_{\mathrm{a}}$, which means one independent variable affects insignificantly on the dependent variable.

- If tarithmetic > table then $\mathrm{H}_{0}$ rejected and $\mathrm{H}_{\mathrm{a}}$ accepted, which means one independent variable (independent) affect the dependent variable significantly.

FTest (Simultaneous)

The simultaneous test (F-test) is performed to show whether all independent variables simultaneously can affect the dependent variable (Winarno, 2009: 36). Basic decision making:

- If P-value $<\alpha=0,05$, then $\mathrm{HO}$ is rejected and Ha accepted. This means that the independent

- variables together have a significant influence with the dependent variable 
- If P-value $>\alpha=0.05$, then H0 is accepted and Ha is rejected. This means that the independent variables together do not have a significant influence with the dependent

\section{Results and Discussion}

\subsection{Model Paired Test}

In determining the selection of the right model, it will be done Chow Test, Hausman test and Lagrange Multiplier Test. Based on the results of tests conducted, it can be concluded:

\begin{tabular}{|c|c|c|c|c|}
\hline & Metode & & Pengujian & Hasil \\
\hline 1 & Chow Test & & PLS atau Common Effect vs fixed effect & Fixed Effect \\
\hline 2 & Hausmann test & & Fixed Effect vs Random Effect & Random \\
\hline 3 & Lagrange & Common Effect vs Random Effect & Random \\
\hline
\end{tabular}

Table1: Conclusions of Panel Data Regression Model Testing

The results of the panel data regression model test on the three panel data models, the purpose is

to strengthen the conclusion of paired testing, which recommends the use of random effect model to be analyzed further in this study.

Dependent Variable: HARGASAHAM?

Method: Pooled EGLS (Cross-section random effects)

Sample: 20132015

Included observations: 3

Cross-sections included: 28

Total pool (balanced) observations: 84

Swamy and Arora estimator of component variances

\begin{tabular}{|c|c|c|c|c|}
\hline Variable & Coefficient & Std. Error & t-Statistic & Prob. \\
\hline $\mathrm{C}$ & 8.419652 & 3.190278 & 2.639159 & 0.0101 \\
\hline NPL & -0.156575 & 0.069702 & -2.246338 & 0.0275 \\
\hline ROA & -0.819757 & 0.119396 & -6.865852 & 0.0000 \\
\hline EPS & 0.011439 & 0.260523 & 0.043909 & 0.9651 \\
\hline CAR & 0.934764 & 0.082133 & 11.38107 & 0.0000 \\
\hline ВОРО & -1.050526 & 0.402400 & -2.610648 & 0.0109 \\
\hline \multirow[t]{2}{*}{ LDR } & -0.096756 & 0.455615 & -0.212364 & 0.8324 \\
\hline & \multicolumn{3}{|c|}{ W eighted Statistics } & \\
\hline R-squared & 0.660439 & Mean dependent var & & 1.975651 \\
\hline Adjusted R-squared & 0.633980 & S.D. dependent var & & 0.453624 \\
\hline S.E. of regression & 0.274441 & Sum squared resid & & 5.799459 \\
\hline F-statistic & 24.96059 & Durbin-Watson stat & & 2.037914 \\
\hline \multirow[t]{2}{*}{ Prob(F-statistic) } & 0.000000 & & & \\
\hline & \multicolumn{3}{|c|}{ Unweighted Statistics } & \\
\hline $\begin{array}{l}\text { R-squared } \\
\text { Sum squared resid }\end{array}$ & $\begin{array}{l}0.835534 \\
26.59135\end{array}$ & $\begin{array}{l}\text { Mean denendent var } \\
\text { Durbin-Watson stat }\end{array}$ & & $\begin{array}{l}6.794087 \\
0.444460\end{array}$ \\
\hline
\end{tabular}

Table 2: Random Effects Test Results

Source: Data is processed with E-Views 8.0

Based on the results of multiple regression analysis above, it can be obtained a regression line equation as follows:

$\hat{\mathrm{Y}}=8,419652-0,156575 \mathrm{NPL}-0,819757 \mathrm{ROA}+0,011439 \mathrm{EPS}+0,934764 \mathrm{CAR}-$ 1,050526 BOPO - 0,096756 LDR

Based on the above equation, it can be interpreted as follows:

- The constant a of 8.419652 states that if the variables $\mathrm{X} 1, \mathrm{X} 2, \mathrm{X} 3, \mathrm{X} 4, \mathrm{X} 5$, and $\mathrm{X} 6$, are constant, then the Y variable is 8.419652 .

- Regression coefficient X1 equal to -0.156575 states that every increase of Non Performing Loans (NPL) of $1 \%$ will 
impact on the decline in bank stock price of Rp.0.156575 with the assumption of other independent variables the magnitude of the constant.

- The regression coefficient X2 of - 0.819757 states that any increase of Return on Assets (ROA) of

- $1 \%$ will have an impact on the decline in bank stock price of Rp.0,819757 with the assumption

- of other independent variables the magnitude of the constant.

- The regression coefficient of X3 of 0.011439 states that each increase of Earning per Share (EPS) of 1\% will have an impact on the increase in bank stock price of Rp.0.011439 with the assumption of other independent variables of the constants.

- Regression coefficient X4 of 0.934764 states that any increase of Capital Adequacy Ratio (CAR) of $1 \%$ will have an impact on the increase in bank stock price of Rp.0, 934764 with the assumption of other independent variables the amount of the constant.

- The regression coefficient $\mathrm{X}_{5}$ of $-1,050526$ states that any increase in Operational Income Operating Expenses (BOPO) of $1 \%$ will have an impact on the decline in bank stock price of Rp.1.050526 with the assumption of other independent variables the magnitude of the constant.

- The regression coefficient $\mathrm{X}_{6}$ of -0.096756 states that any increase of Loan to Deposits Ratio (LDR) of $1 \%$ will have an impact on the decline in bank stock price of Rp.0.096756 with the assumption of other independent variables of the constant.

Adjusted $\mathrm{R}^{2}=0.633980$, it can be interpreted that the effect of Non Performing Loans (NPL), Return on Assets (ROA), Earning Per Share (EPS), Capital Adequacy Ratio (CAR), Operating Income Operating Expense (BOPO) and Loan to Deposits Ratio (LDR) to bank stock price equal to

$63,398 \%$, while the rest equal to $36,602 \%$ is contribution or influence of other variable not included in this research model.

Testing the significance level to test each coefficient in the partial regression equation. Basically this test is to determine whether each of these coefficients differs significantly from zero

(0). Partial test of Non Performing Loans (NPL), Return on Assets (ROA), Earning Per Share (EPS), Capital Adequacy Ratio (CAR), Operating Income Operating (BOPO) and Loan to Deposits Ratio (LDR) Bank is done in accordance with the hypothesis test plan that has been presented in the previous chapter.

To find the ttable, the researcher uses the real level $\mathrm{ta}_{\mathrm{a}}($ 目 $)=5 \%$, so

$$
\begin{aligned}
\text { ttabel } & =\mathrm{t}(\text { (0/ } / 2)(\mathrm{n}-7) \\
& =\mathrm{t}(0,05 / 2)(84-7) \\
& =\mathrm{t}(0,025)(77) \\
& =1,991
\end{aligned}
$$

Conclusions: The tarithmetic value for the Non Performing Loans variable (X1) is smaller than the -ttable value, ie $2433338<-1,991$ or significance $t(0.0275)<\alpha(0,05)$. Thus $\mathrm{H}_{0}$ is rejected and $\mathrm{H}_{a}$ accepted. So it can be concluded that the variable Non Performing Loans partially have a negative and significant influence on the stock prices of banks listed on the Indonesia Stock Exchange period 2013-2015.

Tarithmetic value for Earning per Share $\left(\mathrm{X}_{3}\right)$ is smaller than ttable value, that is $0,043909<1,991$ or significance $t$ $(0,9651)>\alpha(0,05)$. Thus $\mathrm{H}_{0}$ accepted and $\mathrm{H}_{\mathrm{a}}$ rejected. So it can be concluded that the variable Earning per Share partially have a positive and insignificant effect on the stock price of banks listed on the Indonesia Stock Exchange period 20132015.

The tarithmetic value for Capital Adequacy Ratio (X4) variable is greater than ttable value, that is 11,38107 > 1,991 or significance $t(0,0000)<\alpha(0,05)$. Thus $\mathrm{H}_{0}$ is rejected and $\mathrm{H}_{a}$ accepted. So it can be concluded that the variable Capital Adequacy Ratio partially have a positive and significant influence on the stock prices of banks listed on the Indonesia Stock Exchange period 2013-2015.

The value of tarithmetic for the variable Operational Revenue Operating Expense ( $\mathrm{X}_{5}$ ) is smaller than the -ttable value, ie $-2.610648<-1,991$ or significance $t(0,0109)<\alpha(0,05)$. Thus $H_{0}$ is rejected and $H_{a}$ accepted. So it can be concluded that the variable Operational Revenue Operating Expenses partially have a negative and significant influence on the stock prices of banks listed on the Indonesia Stock Exchange period 2013-2015.

The value of tarithmetic for the Loan to Deposits Ratio $\left(\mathrm{X}_{6}\right)$ variable is greater than the -ttable value, that is $-0.212364>$ 1,991 or significance $\mathrm{t}(0.8324)>\alpha(0,05)$. Thus $\mathrm{H}_{0}$ accepted and $\mathrm{H}_{\mathrm{a}}$ rejected. So it can be concluded that the 
variable Loan to Deposits Ratio partially have a negative and insignificant effect on the stock price of banks listed on the Indonesia Stock Exchange period 2013-2015.

Testing is significant simultaneously (overall significance) in a regression equation based on hypothesis test. Regression analysis results are estimated in table 2. shows the value of Farithmetic $=24.96059$ while the value of $\mathrm{F}$ table at $\alpha=0,05$ and the degrees free ( $\mathrm{dk}$ ) of the numerator $=6, \mathrm{n}=84$,

the free degrees $(\mathrm{dk})$ of the numerator $=77$ is 2.22. So Farithmetic $=24.96059>\mathrm{F}$ table 2.22. This means that $\mathrm{H} 0$ is rejected and Ha is accepted at the level of significance $\alpha=0,05$. It can be concluded that Non Performing Loans (NPL), Return on Assets (ROA), Earning Per Share (EPS), Capital Adequacy Ratio (CAR), Operating Revenue Operating (BOPO) and Loan to Deposits Ratio (LDR) Together significant effect on the stock price of banks listed on the Indonesia Stock Exchange period 2013-2015.

\section{Results Interpretation of Research}

\subsection{The Influence of Non Performing Loans (NPL) on Stock Prices}

The result shows that Non Performing Loan has negative and significant effect to stock price. A low Non Performing Loan (NPL) indicates better bank financial performance. This affects the stock price which also increases from year to year. Information published by the company will certainly provide a signal for investors in taking a decision to invest. The high number of problem loans in a bank resulted in falling stock prices. This research is in accordance with the results of Haryeti (2012), Muammar Khaddafi and Ghazali Syamni (2008), and Indra Satria (2015) which stated that Non Performing Loan has negative and significant effect on stock price.

\subsection{Influence of Return on Assets (ROA) on Stock Price}

The results showed Return on Assets has a negative and significant influence on stock prices.

This condition, illustrates that the company's ability to gain profit and to control all operational and non-operational costs is very low. Since more firms have total assets compared to net income, the likelihood of many unemployed assets is consequently only some investors are eyeing in terms of profit assets. This research is in accordance with the results of research Nurjanti Takarini and Ukki Hayudanto Putra (2013), and Rico Wijaya (2012) which states that the Return on Assets have a negative and significant impact on stock prices.

\subsection{The Effect of Earning per Share (EPS) on Stock Prices}

The result of the research shows that Earning per Share has positive and insignificant influence to stock price. A company's EPS information shows the amount of net profit the company is ready to share for all of the company's shareholders. An investor buys and maintains a company's stock in the hope of obtaining a dividend or capital gain. Therefore, shareholders are usually interested in the EPS figures reported by the company. However, the increase in EPS has no impact on the increase in stock prices significantly. This study is in accordance with the results of research by Oliver Ike Inyiama (2015), and Placido M. Menaje (2012) which states that Earning per Share has a positive and insignificant influence on stock prices.

\subsection{Influence of Capital Adequacy Ratio (CAR) to stock price}

The results showed Capital Adequacy Ratio has a positive and significant effect on stock prices. The higher the CAR value of a bank, the greater the endurance of the bank in the face of troubled bank assets. Good bank resilience also shows good performance, where later demand for bank stock will increase. High demand will then increase the share price of the bank. This research is in accordance with the results of research Nurjanti Takarini and Ukki Hayudanto Putra (2013), Evi Steelyana and Dianto Kurnia (2012), and Fariz Abdullah (2015) stating that Capital Adequacy Ratio has a positive and significant influence on stock prices.

\subsection{The Effect of Operational Income Operating Expenses (BOPO) on Stock Prices}

The results showed Operational Revenue Operating Expenses have a negative and significant

influence on stock prices. When operating costs are down and operating income rises then BOPO will decline and BOPO is assumed with stock prices have a negative relationship, that means lower BOPO ratio means better performance of the bank's management, because it is more efficient in using the existing resources in the company, In this case the company can minimize the level of costs incurred for operational and non-operational activities so that investors will be interested to invest their shares then it can increase stock prices. This research is in accordance with the results of Armanto Witjaksono and Monica Nathalia (2014) research, and Ridwan Nurazi and Berto Usman (2016) which stated that Operational Revenue Operating Expenses have a negative and significant influence on stock prices.

\subsection{The Effect of Loan to Deposits Ratio (LDR) on Stock Prices}

The results showed that Loan to Deposits Ratio has a negative and insignificant effect on stock 
prices. Increased LDR means increased interest income obtained by banks. Means the greater the LDR, the greater the credit disbursed, but the increase does not have a positive impact on the increase in the company's stock price. This research is in accordance with the results of research Nurjanti Takarini and Ukki Hayudanto Putra (2013), Fariz Abdullah (2015) and Pryanka J.V. Polyi, Ivonne Saerang, and Yunita Mandagie (2014) stating that Loan to Deposits Ratio has a negative and insignificant effect on stock prices.

6.7.Influence of Non Performing Loans (NPL), Return on Assets (ROA), Earning Per Share (EPS), Capital Adequacy Ratio (CAR), Operating Income Operating Expense (BOPO) and Loan to Deposits Ratio (LDR)

The result of the research shows that the fundamental factors are Non Performing Loans (NPL),

Return on Assets (ROA), Earning Per Share (EPS), Capital Adequacy Ratio (CAR), Operational Income Operating Expense (BOPO) and Loan to Deposits Ratio (LDR) Together have a significant effect on stock prices. For banking companies that go public are required to include the relevant financial ratios in accordance with the Decree of the Chairman of Bapepam Number KEP-51 / PM / 1996 dated January 17, 1996 (BEI). The investor needs to have a benchmark to see if if he invests in a company he will get a gain if his shares are sold. Investors can use the rate of return as a benchmark to see the expectations of a stock's results. This study is in accordance with the results of Fariz

Abdullah's (2015) study which states that Non Performing Loans (NPL), Return on Assets (ROA), Earning Per Share (EPS), Capital Adequacy Ratio (CAR), Operating Income Operating Expenses

(BOPO) and Loan to Deposits Ratio (LDR) together significantly influence stock prices.

\section{Conclusion} follows:

Based on the description of research results in the previous chapter, it can be concluded as

- Non Performing Loans partially have a negative and significant influence on the stock price of banks listed on the Indonesia Stock Exchange period 2013-2015

- Return on Assets partially has a negative and significant influence on the stock price of banks listed on the Indonesia Stock Exchange period 2013-2015.

- Earning per Share partially has a positive and insignificant effect on the stock price of banks listed on the Indonesia Stock Exchange period 2013-2015.

- Capital Adequacy Ratio partially has a positive and significant influence on the stock price of banks listed on the Indonesia Stock Exchange period 2013-2015.

- Operational Revenue Operating expenses partially have a negative and significant effect on the stock price of banks listed on the Indonesia Stock Exchange period 2013-2015.

- Loan to Deposits Ratio partially has a negative and insignificant effect on the stock price of banks listed on the Indonesia Stock Exchange period 2013-2015.

- Non Performing Loans (NPL), Return on Assets (ROA), Earning Per Share (EPS), Capital Adequacy Ratio (CAR), Operating Income Operating Expenses (BOPO) and Loan to Deposits Ratio (LDR) Significant to the price of bank shares listed on the Indonesia Stock Exchange period 2013-2015.

\section{Suggestion}

Suggestions in research are intended for further researchers interested in developing this study to provide different variations and better results related to the determinants of capital structure and its implications for firm value. Some suggestions can be recommended for further research.

- For the academics who will conduct similar research. This research can be developed using more sample companies and using more diverse sectors. The expected results of the research will be able to determine whether the determinants of financial performance and their implications for stock prices are the same or different among sectors.

- For investors are expected to more closely observe the development of company performance. In this study it can be seen that the investor needs to have benchmarks to know whether if he invests in a company he will get a gain (profit) if the shares are sold. Investors can use the rate of return as a benchmark to see the expectations of a stock's results.

\section{References}

i. Abdullah Fariz dan L. Suryanto, 2015, Analisis Pengaruh Rasio-Rasio CAMEL sebagai Penilaian Tingkat Kesehatan Bank terhadap Harga Saham Perusahaan Perbankan yang Terdaftar di Bursa Efek Jakarta, Jurnal Studi Manajemen dan Organisasi Vol. 1 Nomor 2.

ii. Amanda dan Wahyu Ario Pratomo, 2013, Analisis Fundamental dan Resiko Sistematik terhadap Harga Saham Perbankan yang Terdaftar pada Indeks LQ 45, Jurnal Ekonomi dan Keuangan Vol. 1 No. 3, Februari 2013, p. 216.

iii. Aman, Ambo. 2013. Analisis Kinerja Keuangan dengan Menggunakan Metode Camel pada Bank UmumSwasta Nasional Devisa di Indonesia Tahun 2007-2011.

iv. Bachtiar, Yanuar. 2012. Kinerja Keuangan Terhadap Harga Saham Pada Perusahaan Sektor Agriculture Di Bursa 
Efek Indonesia.

v. Dendawijaya, Lukman, 2015. Manajemen Perbankan, Bogor: Ghalia Indonesia.

vi. $\quad$ Fahmi, Irham. 2012. nalisis Laporan Keuangan. Cetakan Ke-2. Bandung: Alfabeta

vii. Fahmi, Irham. 2014. Pengantar Manajemen Keuangan Teori dan Soal Jawab. Cetakan ketiga. Bandung : Alfabeta.

viii. Hasibuan, H. Malayu SP. 2011. Dasar-Dasar Perbankan, Cetakan Kesebelas,. PT.Bumi Aksara, Jakarta.

ix. $\quad$ Husnan. Suad. 2005. Dasar-Dasar Teori Portofolio dan Analisis Sekuritas, ed. Keempat, UPP AMP

YKPN,

Yogyakarta.

x. $\quad$ Kasmir. 2008. Bank dan Lembaga Keuangan Lainnya. Edisi Revisi 2008. Jakarta: PT. Rajagrafindo

a. Persada.Lumbantoruan, S. 2008. Akuntansi Pajak, Edisi Revisi (4st ed.). Jakarta: PT. Gramedia Widiasarana Indonesia.

xi. $\quad$ Martono dan Agus Harjito. 2012. Manajemen Keuangan. Edisi 3. Yogyakarta: Ekonisia.

a. Mc. Donald, S. Scott dan Timothy W. Koch. 2012. Management of Bank. Sixth Edition. USA: Thomson South Western.

xii. Mudrajad, Kuncoro dan Suhardjono. 2011. Manajemen Perbankan Teori dan Aplikasi. Yogyakarta: BPFE Yogyakarta.

xiii. Nachrowi, Djalal Nachrowi, Hardius Usman. 2012. Pendekatan Populer dan Praktis Ekonometruka untuk

a. Analisis Ekonomi dan Keuangan, Lembaga Penerbit Universitas Indonesia, Jakarta.

xiv. Pakpahan, Rosma. 2010. Pengaruh Faktor-Faktor Fundamental Perusahaan dan Kebijakan Deviden Terhadap Nilai Perusahaan (Studi Kasus pada Perusahaan Manufaktur di BEI tahun 2003 -2007). Jurnal Ekonomi Keuangan, Perbankan, dan Akuntansi.

xv. $\quad$ Pandia, Frianto. 2012. Manajemen Dana dan Kesehatan Bank. Cetakan. Pertama. Jakarta: Rineka Cipta.

xvi. Putri, Andini Fitri. 2011. Pengaruh Profitabilitas, Likuiditas, Pertumbuhan, dan Posisi Kas Terhadap Kebijakan Dividen.

xvii. $\quad$ Rivai, Veithzal Dkk., Commercial Bank Management: Manajemen Perbankan dari Teori ke Praktik. Edisi 1 Cetakan 1. Jakarta: Rajawali Press.

xviii. Riyanto, Bambang. 2011. Dasar-dasar Pembelanjaan Perusahaan. Edisi Keempat. Yogyakarta: BPFE. Setiawan dan Dwi Endah Kusrini. 2010. Ekonometrika. Yogyakarta, Penerbit ANDI.

xix. $\quad$ Sugiyono. 2012. Metode Penelitian Kuantitatif Kualitatif dan R\&B. Bandung: Alfabeta.

xx. Sukardi, David dan Kurniawan Indonanjaya. 2010. Manajemen Investasi Pendekatan Teknikal dan Fundamental untuk Analisis Saham. Edisi 1. Yogyakarta : Graha Ilmu.

xxi. Winarno, Wing Wahyu. 2009. Analisis Ekonometrika dan Statistika dengan Eviews. Edisi Kedua. UPP STIM YKPN. Yogyakarta.

xxii. Jogiyanto Hartono, M. 2010. Teori portofolio dan analisis investasi. Yogyakarta: BPFE. 